\title{
Far-East "Orhon" Inscriptions (720-735 AD) in the view of Andrology
}

1. Member of Historical Committee of European Urological Association (EAU), NL-6842 CV ARNHEM, The Netherlands 2. University of Health Sciences, Medical Faculty, Fatih Sultan Mehmet Hospital, Dept. of Urology, Istanbul, Turkey

\section{SUMMARY}

INTRODUCTION: The stone monuments named as "Orhon" inscriptions located in Middle Asia are considered the first written Turkish findings. Our aim was to discuss the contents and physical appearance of the monuments according to the andrological perspective.

METHODS: These inscriptions were composed of three stone monuments built in the years 720-735 AD, in honor of three Khagans (Ruling leaders).

RESULTS: Although the theme of the writings emphasizes the male-dominant ruling style of the antique Middle Asian migratory tribes, we claim that the most interesting point was that the phallus had a secret role in the perspective of the stone monuments.

CONCLUSION: The trilogy of power, state authority, and erection was monumentalized in 8th-century inscriptions. The signs of Andrology should be sought in history, archeology, and art to expand the esthetic horizon of modern medical sciences.

KEYWORDS: Andrology/history. Far East. Science in the Arts.

The "Orhon" Inscriptions (720-735 AD) at the monumental carved rocks located inside what is currently Mongolia are the first known written Turkish findings regarding their history. This was noteworthy considering that antique Middle Asian tribes had a migratory lifestyle, rather than a settled one, and based on animal herd economy. These kinds of local groups are still present in territorial areas. Based on records from available archives, the first findings about Orhon inscriptions were published by a traveler whose full name is Alâeddin Atâ Melik Cüveynî. He was born in the northeast region of today's State of Iran, which belonged to the State of Khorosan in the past, and, in 1226, wrote a work entitled "Tarikh-i Jahangushayi
Juvaini- Tarih-i Cihanguşa (History of World Con-

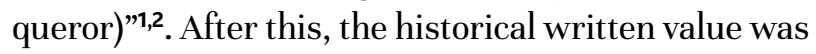
forgotten for a long time. The original monuments were rediscovered in the $18^{\text {th }}$ century by a Swedish military officer named Von Strahlenberg when he was imprisoned by the Russian Army in the region. Subsequently, it was published in 1730 in Stockholm to be presented into the Modern Science of the World ${ }^{1}$. This topic in written form drew the attention of modern Turkish authorities in Istanbul when it was first published by a newspaper, "Ikdam", in 1895. According to Ergin's reviews about Orhon findings, these inscriptions definitely involved the term of monument both materially and spiritually, and they are also a type of 
art-themed writings exuberantly written with senses of gratefulness towards the authorities of the government of the time ${ }^{3}$.

The Orhon Inscriptions were made up of three monuments, which were built between the years 720 and 735, in honor of three Khagan (Ruling leader) whose names were Kul Tigin, Bilge Khagan, and Tonyukuk'. While Tonyokuk's was established for himself, Bilge Khagan did it for Kül Tigin, and the next Khagan provided the inscription for Bilge Khagan ${ }^{1}$. While these inscriptions were narrating Turkish Nation's fight for freedom in an epic language, they were also important for people who were governing the state to identify their responsibilities. This case was a primitive specific example of having governors monitored by the public, what we call democracy in our modern world.

In this study, my aim was to interpret possible reflections of these inscriptions in terms of andrology regarding content and shape. With some exceptions of female administrative figures, such as Istemi khan Hatun (khan Hatun; appellation for a high-rank female official) who were beyond that era as mentioned in the

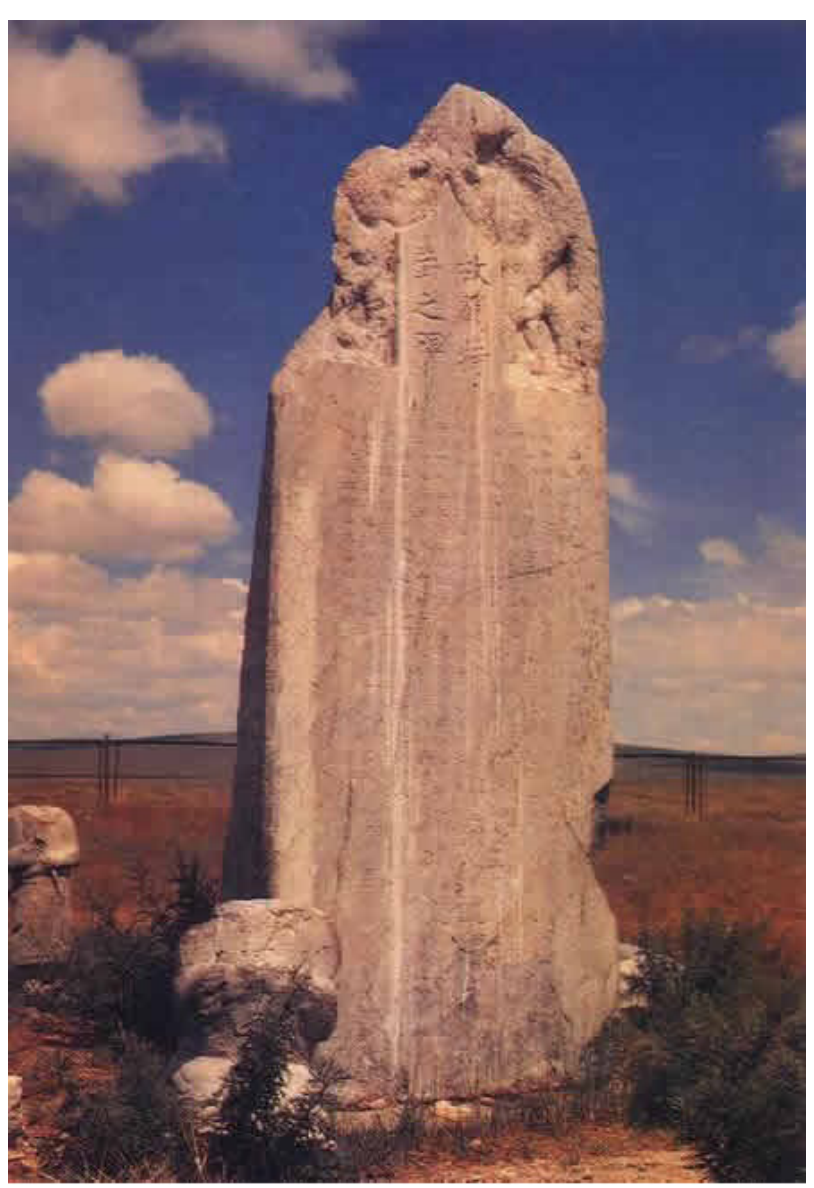

FIGURE 1. MONUMENT OF BILGE KHAGAN. inscriptions, it was not wrong to interpret that the mentality at the root of Turkish state governments was male-dominant ${ }^{3}$. Also, the antinomy of "Fatty bull - Scrawny bull”, ${ }^{1}$, which was repeated in some parts of the inscriptions, can be noted as a reflection of the male-dominant ruling system in a representative way of male sexual authority. Furthermore, as it was reported in the inscriptions, fears of losing the state governance as a result of wars and having the ruling class female members captured by authorities of the enemy mentioned in terms of sexuality were explicitly and exaggeratedly expressed with statements as: "The hero rode his horse and lanced nine men and did not let them to conquere the ruling center. My nursing mother and my mother, elder sisters, daughter-in-laws, princesses would almost have been odalisques (female slaves) altogether."

I think that the descriptions on the monuments, in terms of Andrology, as explained in the context above, actually compose an entirety with shapes of the monuments as well. It will definitely be unfair if the monuments of Orhon Inscriptions were just regarded as simple stone monuments. All three of them stand like they make connections between the Yer Tanri (The Gods of the ground which are types of geographic entities like mountains, rivers, forests, etc.) and Gok Tanri (The God of the sky, which is the most common belief) with their geometric shapes of compound rectangles and cylinders. However, old Turkish populations prioritized political authority instead of religion phenomena ${ }^{4}$. Describing the geometric combination of the monument of Bilge Khagan as an erect penis would not be an exaggeration (Figure 1). Moreover, in social complex Tonyukuk, the explicit similarity between some worn body pieces without a head as an erected penis can easily be detected by close inspection (Figure 2). These kinds of erect phallic monuments as worshipping items had been used almost in the same period in Europe, and interestingly, early Christianity also tolerated these prehistoric menhirs* by adding a Celtic cross at the top ${ }^{5}$. Indians also used phallic stone menhirs with a special name of 'Lingam' ${ }^{6}$. Prehistoric Far East cultures such as the Japanese also had similar stone phalluses for aesthetic reasons rather than religious. Thus, this point of view intersects with antique Asian Turkish tribes ${ }^{7}$. A few centuries later, in the same territory of the present "Karakorum" Mongolia as the first capital of Genghis Khan as a middle Asian leader, a fantastic stone phallus was laid down across green hills, which probably symbolized the female 
FIGURE 2. ANTIQUE SOCIAL COMPLEX OF TONYUKUK. ATTENTION TO STANDING STATUE THAT CARVED AS IN THE FORM OF PHALLUS.

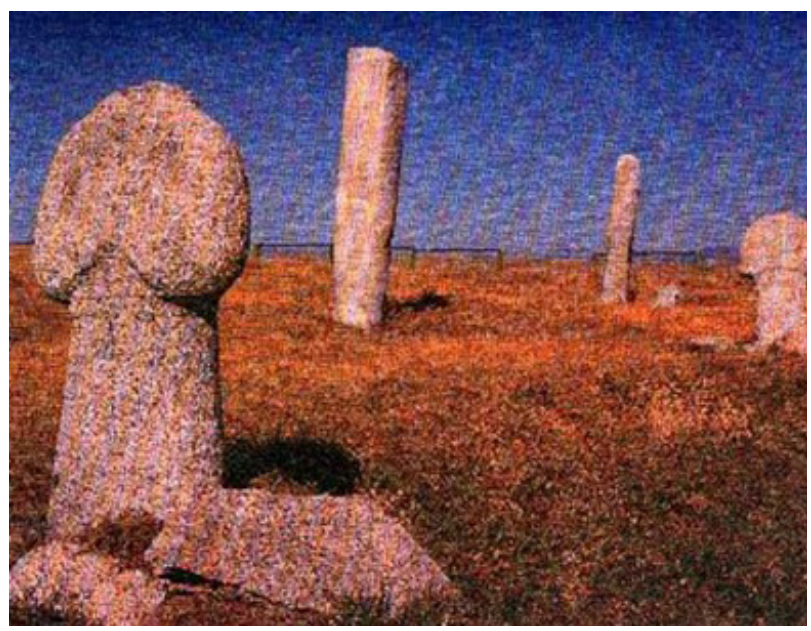

genitals, to improve the renewing of the environment (Figure 3$)^{8}$.

In another speculation about the Tonyukuk monument, even the detail at the intersection of the plump glans penis and corpus penis was explicit in standing style of the human body without a head, in the figure. Furthermore, the erect penis seemed circumcised. Based on that evidence, the present study supports the hypothesis that advocates that circumcision was also common among prehistoric Middle Asians who lived before Islam. Although the first written report of circumcision is by Herodotus ( $5^{\text {th }} \mathrm{BC}$ ), the Greek historian and father of History, in antique Egypt, Mattelaer ${ }^{9}$ reported that circumcision is supposed to be one of the oldest surgical practices of the humankind, with traces of it even in Neolithic cave paintings.

In conclusion, this study believes that the trilogy of power, state authority, and erection was
FIGURE 3. A LARGE PHALLIC STONE FOUNDED BY GENGHIS KHAN IS LAYING THROUGH THE GREEN HILLS WHICH POSSIBLY REPRESENTS THE FEMALE GENITALS. KARAKORUM, MONGOLIA

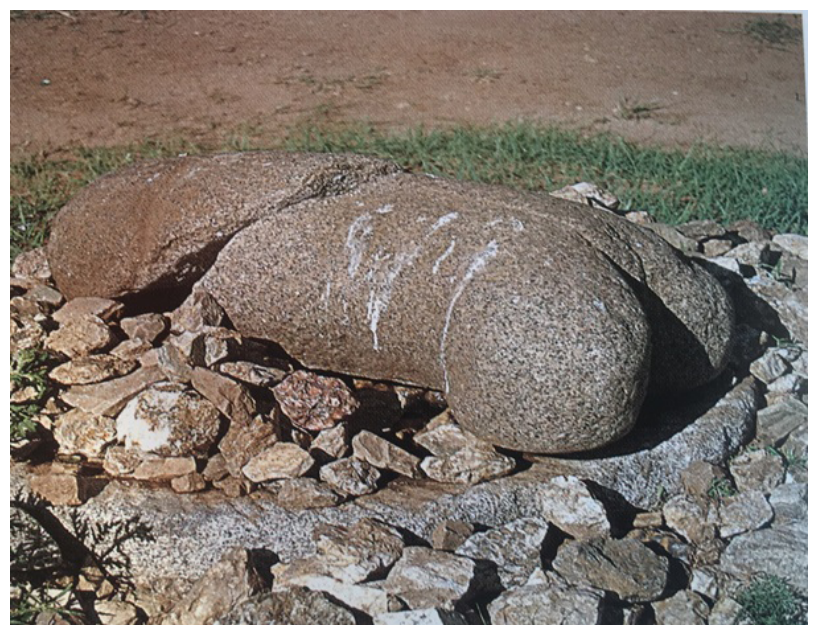

monumentalized in the $8^{\text {th }}$ century Orhon Inscriptions, as has been reported in other cultures of premodern times. The evidence of Andrology should be followed throughout history, archeology, art to expand the aesthetic horizon of modern medical sciences.

\section{Footnote}

*A menhir (from Brittonic languages: maen or men, «stone» and hir or hîr, «long»), standing stone, orthostat, lith is a large human-made upright stone, typically dating from the European middle Bronze Age. They can be found solely as monoliths, or as part of a group of similar stones. https://en.wikipedia.org/wiki/ Menhir

P.S. Figure 1, 2, and 3 are from references 3 and 8 with kind permissions of Altun G; chairman of Bogazici Press, Istanbul, and Mattelaer JJ; EAU Historical Committee, Arnhem, the Netherlands respectively.

\section{RESUMO}

INTRODUçÃo: Os monumentos de pedra denominados inscrições "Orhon", localizados na Ásia Central, são considerados os primeiros achados escritos da Turquia. Nosso objetivo foi discutir os conteúdos e a aparência física dos monumentos de acordo com o ponto de vista andrológico.

MÉTODOS: Essas inscrições foram compostas de três monumentos de pedra construídos nos anos 720-735 d.C., para as honras de três Khagans (líderes de governo).

RESULTADOS: Embora o tema dos escritos fosse enfatizar o estilo dominante masculino das antigas tribos migratórias da Ásia Média, alegamos que o ponto mais interessante era que o falo tinha um papel secreto nas perspectivas dos monumentos de pedra.

CONCLUSÃO: A trilogia de poder, autoridade estatal e ereção foi monumentalizada em inscrições do século VIII. Os sinais da andrologia devem ser buscados na história, na arqueologia e na arte relacionada, no sentido de ampliar o horizonte estético das ciências médicas modernas. 


\section{REFERENCES}

1. Aytaş G, Sami S. Orhun Abideleri. Monuments of Orhun. 2nd ed. Ankara: Akçağ Press; 2013. p.9-12.

2. Alâeddin Atâ Melik Cüveynî. [cited 2019 Jul 12]. Available from: https:// tr.wikipedia.org/wiki/Alaeddin_Ata_Melik_C\%C3\%BCveyni

3. Ergin M. Orhun Abideleri. Monuments of Orhun. 49th ed. Istanbul: Boğaziçi Press; 2015. p.15-24.

4. [cited 2019 Jul 12]. Available from: www.kulturelbellek.com/islamiyet-oncesi-turklerde-din-ve-inanc/ (website in Turkish)

5. Mattelaer |). The old phallic cultures live on during the middle ages in Western Europa. The middle ages. In: Mattelaer J), ed. Sexological and other less logical stories: a tale of love, lust and the living body. Arnhem: European Association of Urology (EAU) and Davidsfonds Uitgeverij nv Press; 2013. p.40-53.
6. Mattelaer JJ. The cult of the Lingam in India. In: Mattelaer JJ, ed. The phallus in art and culture. Arnhem: Historical Committee of the European Association of Urology (EAU) Press; 2000. p.54-67.

7. Mattelaer ||. The phallus in Japan. In: Mattelaer |J, ed. The phallus in art and culture. Arnhem: Historical Committee of the European Association of Urology (EAU) Press; 2000. p.68-71.

8. Mattelaer JJ. The phallus in Chine and Mongolia. In: Mattelaer JJ, ed. The phallus in art and culture. Arnhem: Historical Committee of the European Association of Urology (EAU) Press; 2000. p.72.

9. Mattelaer ||. 5000 years of circumcision. In: Felderhof E, Mattelaer II, Moll F, Schultheiss D, Kerrebroeck P, eds. Milestones in Urology. Arnhem: European Association of Urology (EAU) and Davidsfonds Uitgeverij nv Press; 2013. p.19-29. 